\title{
PENGARUH INTENSITAS CAHAYA MATAHARI DANKETERSEDIAAN AIR TERHADAP PERTUMBUHAN TANAMAN CABAI RAWIT (Capsicum frutescens L.)
}

\section{The Effect Of Sun Light Intensity And Water On Growth Of Cayenne Pepper (Capsicum frutescens L.)}

\author{
Ajis ${ }^{*}$ dan Wahyu Harso \\ Jurusan Biologi Fakultas Matematika dan Ilmu Pengetahuan Alam Universitas Tadulako Tondo \\ Palu, Sulawesi Tengah 94118
}

Keywords:

Cayenne pepper, sunlight intensity and grond water content.
Kata Kunci:

Cabai rawit, intensitas sinar matahari dan kadar air.

\begin{abstract}
Light intensity is one the most important factor to the growth of Capsicum frutescens L, however high light intensity can cause high evaporation which causes plant suffering from drought. The aim of this study was to determine the effect of different sunlight intensities and soilwater availabity to $C$. frutescens growth. The study was conducted by a completely randomized design method with two factors. The first factor was light entensity which consisted of 100 and $50 \%$ sunlight intensity (4287 and 2587 lux). The second factor was soil water avaibility which consisted of 75,50 and $25 \%$ fied capacity. The results showed that plants grown at $100 \%$ light intensity had higher growth than plants grown at $50 \%$ light intensity on every soil water availability treatments. Soil water availability was not significantly affecting plant growth. It might be caused by plant received short period of sunlight.
\end{abstract}

\begin{abstract}
ABSTRAK
Intensitas cahaya adalah salah satu faktor terpenting untuk pertumbuhan Capsicum frutescens $L$, namun intensitas cahaya yang tinggi dapat menyebabkan penguapan yang tinggi yang menyebabkan tanaman menderita kekeringan. Tujuan dari penelitian ini adalah untuk mengetahui pengaruh intensitas sinar matahari yang berbeda dan ketersediaan air tanah terhadap pertumbuhan $\mathrm{C}$. frutescens. Penelitian ini dilakukan dengan metode desain acak lengkap dengan dua faktor. Faktor pertama adalah entensitas cahaya yang terdiri dari intensitas cahaya matahari 100 dan 50\% (4287 dan 2587 lux). Faktor kedua adalah ketersediaan air tanah yang terdiri dari 75,50 dan $25 \%$ kapasitas. Hasil penelitian menunjukkan bahwa tanaman yang tumbuh pada intensitas cahaya $100 \%$ memiliki pertumbuhan lebih tinggi daripada tanaman yang tumbuh pada intensitas cahaya $50 \%$ pada setiap perlakuan ketersediaan air tanah. Ketersediaan air tanah tidak berpengaruh signifikan terhadap pertumbuhan tanaman. Ini mungkin disebabkan oleh tanaman menerima sinar matahari periode pendek.
\end{abstract}

Corresponding Author : ajisajis@gmail.com 


\section{PENDAHULUAN}

Cabai rawit merupakan jenis sayuran yang bisa dikonsumsi dallam rumah tangga atau untuk peneyedap saus dan produkproduk makanan kaleng (Simanungkalit, 2008). Cabai rawit biasa di budidayakan di daerah tropis di dataran rendah maupun dataran tinggi baik pada musim hujan maupun musim kemarau (Rosid dan Syahuri, 2015).

Dalam proses budidaya, intensitas cahaya matahari sangat berpengaruh terhadap pertumbuhan tanaman (Rawi, 2012). Intensitas cahaya matahari yang tinggi di daerah tropis disisi lain akan

\section{BAHAN DAN METODE}

Penelitian dilakukan pada bulan Desember sampai Januari 2019 di Jurusan Biologi FMIPA Universitas Tadulako.

\section{Rancanagan Penelitian}

Penelitian dilakukan dengan menggunakan Rancangan Acak Lengkap dengan dua perlakuan yaitu perlakuan pertama berupa intensitas cahaya matahari yang terdiri dari $100 \%$ intensitas cahaya matahari (4287 lux) dan 50\% intensitas cahaya matahari (2858 lux). Untuk perlakuan kedua berupa kadar air dalam tanah sebagai media tanam yang terdiri dari $75 \%$, 50\% dan 25\% kapasitas lapang masing-masing kombinasi perlakuan diulang sebanyak empat kali.

\section{Prosedur Penelitian}

ISSN-P : 1978-6417; ISSN-E : 2580-5991 evapotranspirasi (Mathius et., 2001). Dengan tingginya evapotranspirasi akibat intensitas cahaya yang tinggi akan menghambat pertumbuhan bila kondisi tanah tidak cukup air (Setiawan, 2015).

Kekurangan air pada tanaman akan menyebabkan kelayuan daun, tanaman menjadi kerdil dan hasil panen yang menurun (Arif, 2011). Kekurangan air juga akan menyebabkan tanaman mudah diserang oleh penyakit (Herawati, 2007). Untuk itu perlu dilakukan penelitian mengenai interaksi intensitas cahaya matahari dan ketersediaan air di dalam tanah terhadap pertumbuhan tanamn cabai.

Penelitian dilakukan dengan menggunakan Rancangan Acak Lengkap dengan dua perlakuan yaitu perlakuan pertama berupa intensitas cahaya matahari yang terdiri dari 100\% inttensitas cahaya matahari (4287 lux) dan 50\% intensitas cahaya matahari (2858 lux). Untuk perlakuan kedua berupa kadar air dalam tanah sebagai media tanam yang terdiri dari $75 \%$, 50\% dan 25\% kapasitas lapang masing-masing kombinasi perlakuan diulang sebanyak empat kali. Tanah diambil dari lingkungan disekitar Jurusan Biologi FMIPA Universitas Tadulako dengan cara menggali tanah sampai kedalaman 20 $\mathrm{cm}$, kemudian tanah diaduk secara merata dan dikering anginkan selama 3 hari. Sebelum digunakan sebagai media tanam, 
kadar air dalam tanah dan kapasitas lapang tanah diukur. Sebanyak $4 \mathrm{~kg}$ tanah dimasukkan ke dalam polybag ukuran $25 x$ $30 \mathrm{~cm}$ kemudian tiga biji cabai rawit yang sudah diseleksi dimasukkan ke dalam polybag dengan kedalaman $3 \mathrm{~cm}$. Setelah itu tanah diberi air sampai $100 \%$ kapasitas lapang sampai tanaman berumur 14 hari setelah tanam. Setelah berumur 14 hari setelah tanam, tanaman cabai disisakan menjadi satu pada masing-masing polybag dengan melihat tingkat keseragaman yang tinggi dengan cara memotong pada bagian pangkal batangnya. Perlakuan kadar air dalam tanah diberikan setelah tanaman berumur 14 hari setelah tanam.

Pengamatan parameter pertumbuhan berupa tinggi tanaman, berat kering tanaman dan luas daun. Pengukuran tinggi tanaman dilakukan dengan mengukur

\section{HASIL DAN PEMBAHASAN}

Hasil penelitian menunjukkan bahwa intensitas cahaya sangat mempengaruhi pertumbuhan tanaman. Tanaman yang diberi perlakuan intensitas cahaya sebesar 100\% atau 4287 lux memiliki parameter pertumbuhan tanaman (tinggi tanaman, berat kering tanaman dan luas daun) yang lebih tinggi dibandingkan tanaman yang diberi intensitas cahaya $50 \%$ atau 2528 lux pada setiap kadar air yang diberikan (Gb. 1, 2 dan 3). Meskipun setiap jenis tanaman panjang dari pangkal batang sampai daun teratas. Berat kering tanaman diukur setelah tajuk dan akar tanaman dioven selama 48 jam pada suhu $80^{\circ} \mathrm{C}$. Luas daun diukur dengan menggambar seluruh daun pada masing-masing tanaman dengan menggunakan kertas HVS A4 $70 \mathrm{~g}$. Gambar yang terbentuk kemudian digunting lalu ditimbang. Untuk mengukur luas daun maka berat masing-masing kertas dari hasil guntingan tadi dibagi dengan berat kertas HVS $70 \mathrm{~g}$ dengan ukuran $1 \times 1 \mathrm{~cm}$.

\section{Analisis Data}

Data yang diperoleh dari hasil pengamatan untuk setiap parameter dianalisis menggunakan Anova dua Arah (Two Way Anova) yang kemudian diuji lanjut dengan DMRT (Duncan Multiple Range Test) pada taraf uji $5 \%$.

memerlukan tingkat intensitas cahaya tertentu untuk melakukan fotosintesisnya secara optimum.

Cahaya merupakan faktor penting terhadap berlangsungnya fotosintesis, sementara fotosintesis merupakan proses yang menjadi kunci dapat berlangsungnya proses metabolism yang lain di dalam tanaman (Kramer dan Kozlowski, 1979). Fotosintesis dilakukan untuk membentuk karbohidrat dengan menyatukan $\mathrm{CO}_{2}$ dan $\mathrm{H}_{2} \mathrm{O}$. 


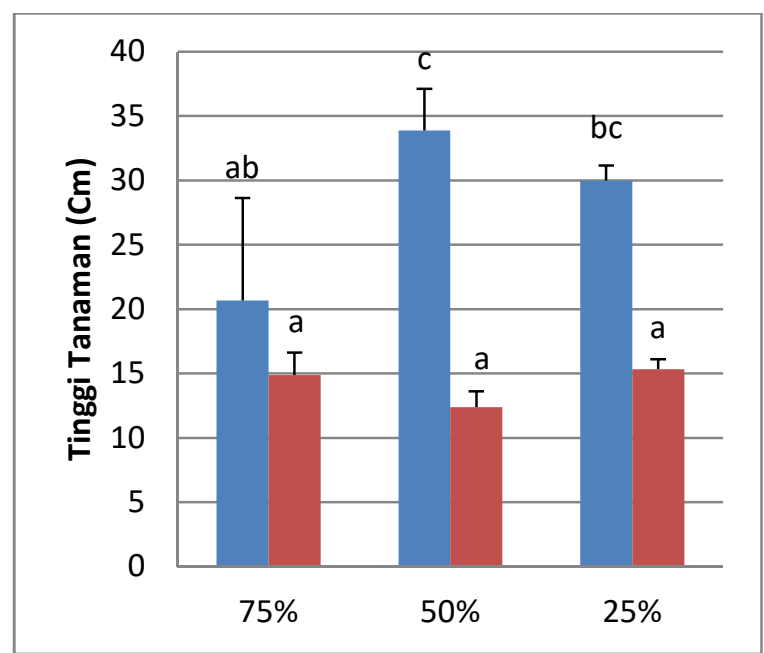

Gambar 1. Tinggi tanaman umur 28 hari setelah tanam dengan kandungan air tanah yang diberikan yaitu $75 \%, 50 \%$ dan $25 \%$ kapasitas lapang. Batang grafik berwarna biru adalah tanaman yang terpapar cahaya matahari $100 \%$, sedangkan batang grafik yang berwarna merah adalah tanaman yang terpapar cahaya matahari $50 \%$. Nilai yang ditunjukan pada grafik adalah nilai ratarata \pm standar deviasi. Grafik yang diikuti oleh huruf yang sama menunjukkan tidak berbeda nyata.

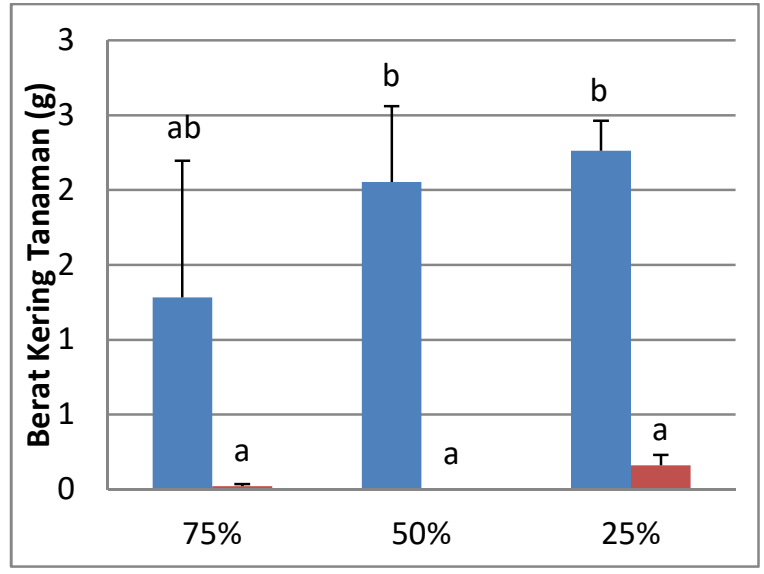

Gambar 2. Berat kering tanaman umur 28 hari setelah tanam dengan kandungan air tanah yang diberikan yaitu $75 \%, 50 \%$ dan $25 \%$ kapasitas lapang. Keterangan gambar dapat merujuk pada Gb. 1.

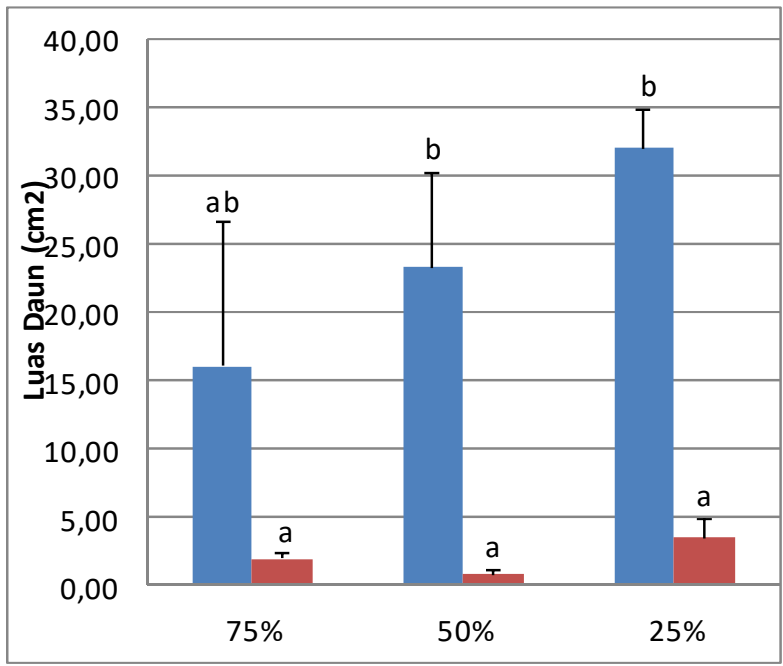

Gambar 3. Berat kering tanaman umur 28 hari setelah tanam dengan kandungan air tanah yang diberikan yaitu $75 \%, 50$ $\%$ dan $25 \%$ kapasitas lapang. Keterangan gambar dapat merujuk pada Gb. 1.

Menurut Arsyad dkk.,

(1997)

Karbohidrat atau senyawa heksosa yang terbentuk akan digunakan sebagai substrat respirasi untuk diubah menjadi bahanbahan struktural, cadangan makanan, dan metabolit lain yang dibutuhkan untuk pertumbuhan dan perkembangan (Gardner dkk., 1991). Hal ini sejalan dengan penelitian yang dilakukan oleh Parman (2010) bahwa tanaman lobak yang diberi intensitas cahaya tinggi memiliki luas daun yang lebih tinggi dibandingkan dengan tanaman lobak yang diberi intensitas cahaya sedang maupun rendah. Lebih tingginya luas daun akan menyebabkan semakin tingginya berat kering umbi yang dihasilkan. Hal ini disebabkan oleh kemampuan yang lebih tinggi untuk melakukan fotosintesis pada daun yang lebih luas. 
Air berperan sebagai pelarut, media terjadinya reaksi, penyusun utama sel, serta menjaga turgiditas dalam sel dan pembukaan stomata. Kekurangan air akan menyebabkan tanaman menjadi kerdil dan perkembangannya menjadi abnormal. Kekurangan air yang terus menerus selama pertumbuhannya akan menyebabkan tanaman tersebut menderita dan kemudian mati (Kurniawan dkk., 2014). Dengan demikian ketersediaan air akan menentukan keberhasilan produksi tanaman baik secara vegetative maupun generative karena air merupakan kebutuhan dasar dari bagi tanaman. Efisiensi pemakaian air tertinggi pada kadar air tanah antara 55-70\% kapasitas lapang sehingga kekurangan atau kelebihan air akan mempengaruhi pertumbuhan dan produksi dari tanaman (Supriadi dkk., 2018).

Penelitian yang dilakukan oleh Marsah dkk. (2014) menyebutkan bahwa kadar air $50 \%$ dan $25 \%$ tersedia menurunkan jumlah daun yang terbentuk dibandingkan dengan pemberian $75 \%$ air tersedia. Pada

\section{DAFTAR PUSTAKA}

Arif, U., Sri Darmanti, dan Sri Haryanti. (2011). Pertumbuhan produktivitas bawang merah (Allium ascalonicum L.Var.Tiron) dengan perlakuan Glacilaria verrucosa sebagai penyerap air pada tanah pasir. Bioma. 13(2), 60-66. perlakuan $25 \%$ air tersedia juga akan menyebabkan tinggi tanaman Crotalaria mucronata lebih rendah dibandingkan dengan tanaman diuji yang diberi $50 \%$ dan $75 \%$ air tersedia.

Pada penelitian ini, kadar air yang diberikan yaitu $75 \%$, 50\% dan 25\% air kapasitas lapang tidak berpengaruh terhadap parameter pertumbuhan tanaman yang diamati. Meskipun tanaman cabai sensitif dengan kekurangan air karena sistem perakaran yang dangkal (Supriadi dkk., 2018). Hal ini mungkin disebabkan oleh kurang lamanya tanaman terkena cahaya matahari. Tanaman terkena cahaya matahari mungkin hanya sekitar 4-5 jam karena rumah plastik terhalang oleh bangunan di pagi hari dan pohon-pohon pada saat menjelang sore hari. Kurangnya lama pencahayaan matahari pada rumah kaca akan menyebabkan kurangnya evapotranspirasi yang terjadi pada penelitian ini yang menyebabkan kadar air dalam pollybag tidak berpengaruh terhadap parameter pertumbuhan yang diamati.

Arsyad, M., Asadi, D., Darmijati, dan Zahra, H. (1997). Pemuliaan kedelai untuk Toleran Naungan dan Tumpangsari. Jurnal Agrobio Balai Penelitian Bioteknologi Tanaman Pangan Bogor. 1(2), 15-20.

Gardner, F. P., Pearce, R. B., dan Mitchell. R. L. (1991). Fisiologi tanaman budidaya. Penerjemah: Susilo, H. dan 
Subiyanto. Jakarta: Universitas Indonesia Press.

Herawati, A. (2007). Pengaruh kekurangan air (Water Defisit) terhadap pertumbuhan dan perkembangan tanaman tembakau. Jurnal Inovasi Pertanian. 6(1), 44-51.

Kurniawan, B, A., Arifin, dan Fajriani, S. (2014). Pengaruh Jumlah Pemberian Air Terhadap Respon Pertumbuhan dan Hasil Tanaman Tembakau (Nikotiana tabaccum L.). Jurnal Produksi Tanaman. 2(1), 59-64.

Kramer, P, J., dan Kozlowski, T., T. (1979). Physiology Of Woody Plants. Florida: Academic Press.

Marsah, N, D., Aini, N, dan Susan, T. (2014). Pengaruh frekuensi dan volume pemberian air pada pertumbuhan tanaman (Crotalaria mucronata Desv). Jurnal Produksi Tanaman. 2(8), 673-678.

Mathius, N, T., Guharja, E., and Wijana, G. (2001). Respon tanaman kelapa sawit (Elaeis guineensis Jacd.) terhadap cekaman kekeringan. Menara perkebunan. 69(2), 29-45.

Parman, S. (2010). Pengaruh intensitas cahaya terhadap produksi umbi tanaman lobak (Raphanus Sativus L). Buletin 18(2), 8-9 . Laboratorium biologi struktur dan fungsi tumbuhan jurusan biologi Fakultas MIPA Universitas Diponegoro. Yogyakarta.

Rawi, (2012). Adaptasi Jagung (Zea mays L.) Kultivar Lokal Merah Sigi dan Varietas Lamuru Terhadap Kekeringan. Skripsi. Fakultas IImu Pengetahuan Alam Universitas Tadulako. Palu.

Sahuri, dan Rosid, M., J. (2015). Farming Analysis and Optimization of Land between Rubber Rows Using Cayenne Pepper as Intercrops. Warta Perkaretan. 34(2), 77-88.

Setiawan, R. (2015). Pengaruh cekaman kekeringan terhadap pertumbuhan dan karakter protein pada hasil produksi tanaman sorgum (Sorgum bicolor L. Moench). Skripsi. Universitas Jember.

Simanungkalit, R. D. M. (2008)."Pupuk organik dan pupuk hayati". Balai besar litbang sumber daya lahan pertanian badan penelitian pembangunan pertanian. Bogor.

Supriadi, R, D., Susila, D, A., dan Sulistyono, E., (2018). Penetapan Kebutuhan Air Tanaman Cabai Merah. (Capsicum L.) dan Cabai Rawit (Capsicum frutescens L.). Jurnal Hort Indonesia. 9(1), 38-46. 